doi: 10.5862/MCE.68.3

\title{
Moisture sorption models for wood
}

\section{Модели сорбционной влажности древесины}

\author{
R.A. Nazirov, \\ S.V. Verkhovets, \\ I.S. Inzhutov, \\ R.V. Bazhenov, \\ I.V. Tarasov, \\ Siberian Federal University, Krasnoyarsk, Russia
}

Key words: moisture of wood; sorption isotherm; mathematics model; temperature dependent models; numerical calculations of wooden structures

\author{
Д-р техн. наук, зав. кафедрой Р.А. Назиров, \\ канд. с.-хоз. наук, зав. кафедрой \\ C.B. Верховец, \\ д-р техн. наук, директор Инженерно- \\ строительного института И.С. Инжутов, \\ аспирант Р.В. Баженов, \\ канд. техн. наук, доцент И.В. Тарасов, \\ Сибирский федеральный университет, \\ г. Красноярск, Россия
}

\begin{abstract}
Ключевые слова: влажность древесины; изотермы сорбции; математическая модель; модели зависимости температуры; числовые расчеты деревянных конструкций
\end{abstract}

Abstract. While making calculations for non-steady heat-and-moisture exchange processes in building envelope constructions it is necessary to consider moisture sorption isotherms of the materials in use. Fifteen aqueous vapor sorption models have been analyzed in order to select the simplest one that represents conventional equilibrium wood moisture values in the most accurate way. Hailwood-Horrobin and Peleg modified equations with three and four empirical constants respectively are the most suitable ones for description. When selecting models for calculations in a climatically defined range of air temperature and relative humidity values, these equations might be in preference to others. The dependence of the constants in these equations on the ambient air temperature have been calculated.

Аннотация. При расчетах нестационарных процессов тепловлагопереноса в ограждающих конструкциях зданий необходимо знание изотерм сорбционной влажности материалов. Пятнадцать моделей сорбции паров воды проанализированы с позиции выбора наиболее простой и точно описывающей принятые в инженерной практике значения равновесной влажности древесины. Перспективными для описания изотерм сорбции при различных температурах являются модифицированные уравнения Hailwood-Horrobin с тремя и Peleg с четырьмя эмпирическими константами. При выборе моделей для численных расчетов эти уравнения могут иметь приоритетное значение в диапазоне природно-климатических температурно-влажностных вариаций наружного воздуха. Рассчитаны зависимости констант этих уравнений от температуры окружающего воздуха.

\section{Introduction}

The way moisture affects construction materials is thoroughly studied. In most dense construction materials, e.g. cement concrete and mortar, high moisture content at positive temperatures leads to cement hydration, which results in increased hardness and density of the material due to pore colmatation with hydration products and surface carbonation.

In highly porous thermal insulation materials high moisture content increases thermal conductivity, which leads to increased heat loss through building envelope constructions.

In case the thermal conductivity factor that depends on moisture sorption of materials and corresponds with usage conditions A or B according to Construction Regulations SP 50.13330.2012 "Thermal protection of buildings. Updated edition. Construction Norms and Regulations SNiP 23-022003" is used in thermotechnical calculations, construction materials are often overused. Calculation results with regard to material moisture content depending on air temperature and relative humidity in the climatic conditions of Krasnodar, Russia, published in Paper [1] showcase that the reduced total thermal resistance value exceeds the normatively calculated value by 26,15 and 16 percent for single-layer walls

Nazirov R.A., Verkhovets S.V., Inzhutov I.S., Bazhenov R.V., Tarasov I.V. Moisture sorption models for wood. Magazine of Civil Engineering. 2016. No. 8. Pp. 26-36. doi: 10.5862/MCE.68.3 
built of foamed concrete, keramzit concrete and keramzit-perlite concrete respectively. When a triplelayer wall panel was calculated for Moscow climatic conditions, this value was overstated by $29 \%$.

The author states that a higher accuracy of calculations and a lower consumption of construction materials can be achieved by taking into account the dependence of moisture sorption and thermal conductivity of construction materials on temperature when calculating heat and mass transfer values through building envelope constructions and their reduced total thermal resistance.

The article [2] presents the results of comparison between the working moisture content of various construction material samples and the moisture sorption of the same samples at 80 and $97 \%$ relative air humidity. For instance, the working moisture content of a foamed polystyrene sample taken from a construction in Novosibirsk, Russia (usage conditions A) appeared to be almost 60 times higher than the moisture sorption (80\%). For a brick sample from Moscow it was 4 and 10 times higher. The article states that the thermotechnical characteristics of various materials determined by existing construction rules and regulations are outdated. Moreover, there are no such values determined for newer types of materials. The authors of the article suggest that the working moisture content of construction materials be calculated using a non-steady method according to Russian State Standard GOST 32494-2013 "Buildings and Constructions. Mathematical modeling of heat-and-moisture processes for building envelope constructions" with further data correction according to the results of field tests. The accuracy of such method is proved in Paper [3]. The above paper compares the results of calculations with the results of field tests determining working moisture content of mineral wool and foamed polystyrene in Saint-Petersburg, Russia and Novosibirsk. The difference between calculations and test results does not exceed $15 \%$.

Nowadays, wooden house-building is rapidly gaining popularity in European countries. The increased use of wooden constructions made of materials from renewable sources benefits sustainable development. Wooden buildings are in great request because they are built of materials from renewable sources and hence are environmentally friendly. Wooden multi-story buildings are successfully built and used abroad [4].

According to the standard STO 00044807-001-2006 "Heat-protective characteristics of building envelope constructions" developed by the Russian Construction Engineering Association (ROIS), the estimated physical decay period of wooden buildings is 90 years.

Unlike most constriction materials, wood is known for its increased moisture sorption and decay tendency. Moreover, wood is an anisotropic material, which means its thermal conductivity and vapor permeability along the grain are respectively 2 and 5 times higher than across the grain. Thus, it is extremely important to consider the moisture sorption and thermal conductivity dependence on temperature when making calculations for heat and mass transfer processes through building envelope constructions and also to calculate the working sorption content for wooden constructions.

For porous materials the equilibrium moisture content depends on air temperature and humidity. The purpose of this work is to select a simple yet accurate mathematical model describing the published results of equilibrium moisture content and thermal conductivity experiments with wooden and composite constructions for numerical modeling in the range of air temperature and humidity values typical for a certain climate. This work is not aimed at studying physicochemical processes caused by vapor sorption and desorption. Physico-chemical aspects of wood adsorption along with existing theories on the subject were thoroughly studied in papers [5], [6] by B.S. Chudinov, E.A. Kolosovskaya and S.R. Loskutov.

\section{Methods}

According to the classification suggested in Paper [7], there are five types of sorption isotherms.

The International Union of Pure and Applied Chemistry (IUPAC) distinguishes between six types of adsorption [8] illustrated in Figure 1. 


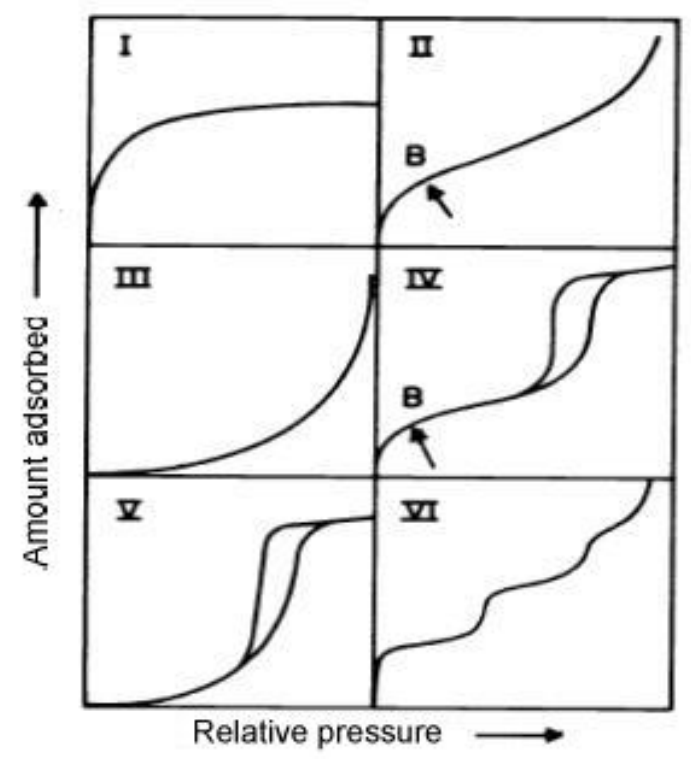

Figure 1. Isotherm types [8]

Isotherm I illustrates monolayer adsorption typical of materials with well-developed inner structures and relatively small surface areas, such as activated charcoal, zeolites and molecular sieves. In this case the limits of adsorption are defined by the micropore volume.

Isotherm II illustrates multilayer monomolecular adsorption in non-porous or coarse-porous adsorbents in conditions of strong interaction between the adsorbate and the adsorbent with a distinguished bending point. It is assumed that this point is where the formation of the monolayer finishes and next layers of the adsorbate start forming.

Isotherm III illustrates adsorption in non-porous or coarse-porous adsorbents in conditions of weak interaction between the adsorbate and the adsorbent. This isotherm is bent towards the partial pressure axis and does not have a distinguished or indistinct bending point.

Isotherm IV characterizes adsorption in conditions of strong interaction between the adsorbate and the adsorbent (type II) when the hysteresis effect takes place. In contrast to the type II, the limit mesopore capillary condensation in the higher range of partial pressure values of the adsorbed gas is distinguished in this case. This isotherm illustrates the adsorption in a hydrophilic material that is swelling to the limit state [9]. This is a typical case for industrial adsorbents.

Isotherm V illustrates adsorption with the hysteresis effect in conditions of weak interaction between the adsorbate and the adsorbent when the limit mesopore capillary condensation in the higher range of partial pressure values of the adsorbed gas is distinguished. Such isotherms are typical for aqueous vapor adsorption by coal.

Isotherm VI characterizes stepwise multilayer adsorption, in which case the height of steps depends on the temperature and the adsorbate-adsorbent system.

Water sorption in most construction materials, including wood, is characterized by Isotherm II (Fig. 2).

Nazirov R.A., Verkhovets S.V., Inzhutov I.S., Bazhenov R.V., Tarasov I.V. Moisture sorption models for wood. Magazine of Civil Engineering. 2016. No. 8. Pp. 26-36. doi: 10.5862/MCE.68.3 


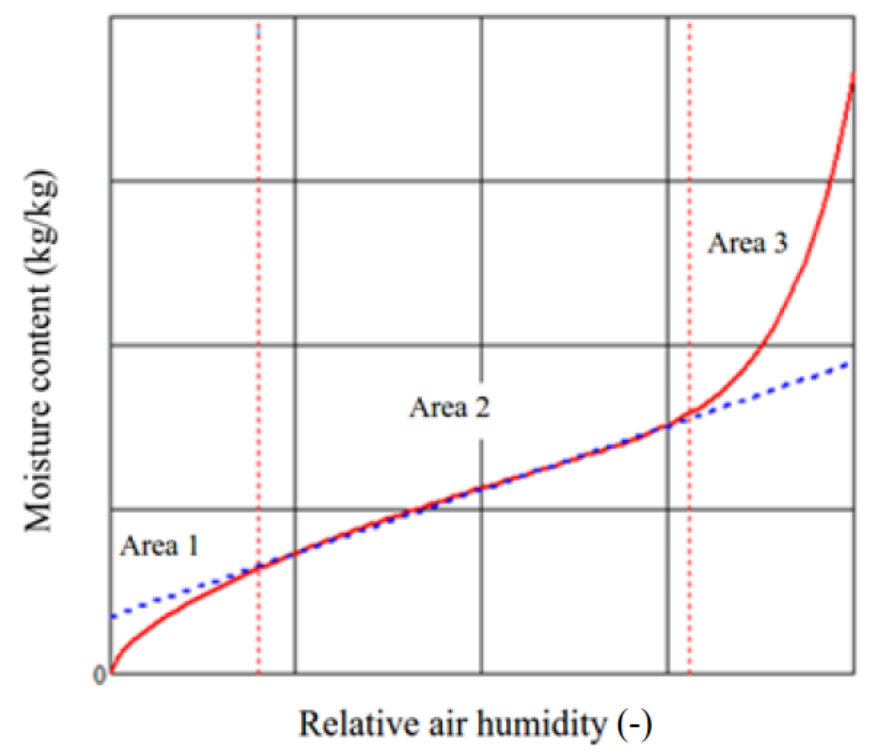

Figure 2. Sorption in wood. Isotherm diagram with areas marked

In Paper [10] the physical sorption mechanism is described in the following way. There are three areas distinguished on the sorption curve. Area 1 of the sorption isotherm illustrates the way the Van der Waals force affects water molecules. Water molecules adsorption continues until the monolayer covering the external cell wall surface forms. At this moment, the water stays in the solid state due to chemical bonds. This area flows to Area 2 when the first layer becomes saturated. At this stage the water molecules adsorption in the first layer takes place which creates the second layer. In this area the isotherm is linear. In Area 3 there might be liquid water in wood capillaries. Supposing that the adsorbed water covers the cell walls evenly in the transition zone between Areas 2 and 3 , the thickness of the layer becomes sufficient for liquid water generation in the pores as the result of capillary condensation. Thus, the microcapillary water forms a continuous phase.

Sorption isotherm equations. Langmuir adsorption isotherm equation (1) assumes that the aqueous vapor condensates as a monolayer and is basic for models considering the adsorption of two or more layers (BET, GAB, H-H, Dent models).

$$
\mathrm{w}=\frac{\mathrm{c} \cdot \varphi \cdot \mathrm{w}_{0}}{\mathrm{c} \cdot \varphi+1}
$$

BET equation was first suggested by Brunauer, Emmet and Teller [11].

$$
\mathrm{w}=\frac{\mathrm{w}_{0} \cdot \mathrm{c} \cdot \varphi}{(1-\varphi) \cdot(1+(\mathrm{c}-1) \cdot \varphi)}
$$

BET (2) is the most commonly used equation and is fundamental for multilayer sorption isotherms interpretation. In this equation, $\mathrm{w}$ is the equilibrium moisture content of the material $(\mathrm{kg} / \mathrm{kg}$ of dry material); $\mathrm{w}_{0}$ is water content in the monolayer adsorbed by dry adsorbent ( $\mathrm{kg}$ of water $/ \mathrm{kg}$ of dry substance); $\varphi$ stands for relative air humidity (water activity), $\mathrm{c}$ is the adsorption heat constant related to the sorption heat difference between the first and the following layers.

BET equation is used in the $0.05-0.45$ air humidity range. BET equation is used for surface area definition. In general, with an arbitrary number of layers ( $n$ ) the BET theory leads to the following equation [9], [10]:

$$
\mathrm{w}=\frac{\mathrm{w}_{0} \cdot \mathrm{c} \cdot \varphi}{1-\varphi} \cdot \frac{\left(1-(\mathrm{n}+1) \cdot \varphi^{\mathrm{n}}+\mathrm{n} \cdot \varphi^{\mathrm{n}+1}\right)}{\left(1+(\mathrm{c}-1) \cdot \varphi-\mathrm{c} \cdot \varphi^{\mathrm{n}+1}\right)}
$$

In the monolayer case $(n=1)$, equation (3) transforms into the Langmuire equation (1).

Hailwood-Horrobin model $(\mathrm{H}-\mathrm{H})$ [12]:

$$
\mathrm{w}=\frac{1800}{\mathrm{M}_{\mathrm{P}}} \cdot\left[\frac{\mathrm{K} \cdot \varphi}{1-\mathrm{K} \cdot \varphi}+\frac{\sum_{\mathrm{i}=1}^{\mathrm{n}} \mathrm{i} \cdot(\mathrm{K} \cdot \varphi)^{\mathrm{i}} \cdot \mathrm{K}_{1} \cdot \mathrm{K}_{2} \ldots \mathrm{K}_{\mathrm{i}}}{1+\sum_{\mathrm{i}=1}^{\mathrm{n}}(\mathrm{K} \cdot \varphi)^{\mathrm{i}} \cdot \mathrm{K}_{1} \cdot \mathrm{K}_{2} \ldots \mathrm{K}_{\mathrm{i}}}\right]
$$


For a monomolecular adsorbed water layer this is written in Paper [13] as:

$$
\mathrm{w}=\frac{1800}{\mathrm{M}_{\mathrm{P}}} \cdot\left[\frac{\mathrm{K}_{2} \cdot \varphi}{1-\mathrm{K}_{2} \cdot \varphi}+\frac{\mathrm{K}_{1} \cdot \mathrm{K}_{2} \cdot \varphi}{1+\mathrm{K}_{1} \cdot \mathrm{K}_{2} \cdot \varphi}\right]
$$

For two monomolecular layers $(n=2)$ this is written in Paper [14] as:

$$
\mathrm{w}=\frac{1800}{\mathrm{M}_{\mathrm{P}}} \cdot\left[\frac{\mathrm{K} \cdot \varphi}{1-\mathrm{K} \cdot \varphi}+\frac{\mathrm{K}_{1} \cdot \mathrm{K} \cdot \varphi+2 \cdot \mathrm{K}_{1} \cdot \mathrm{K}_{2} \cdot \mathrm{K}^{2} \cdot \varphi^{2}}{1+\mathrm{K}_{1} \cdot \mathrm{K} \cdot \varphi+\mathrm{K}_{1} \cdot \mathrm{K}_{2} \cdot \mathrm{K}^{2} \cdot \varphi^{2}}\right]
$$

The effect of temperature on $w$ is taken into account by the functionality of each equation member described by quadric polynomials:

$$
\begin{gathered}
\mathrm{M}_{\mathrm{P}}=349+1.29 \cdot \mathrm{T}+0.0135 \cdot \mathrm{T}^{2} \\
\mathrm{~K}=0.805+0.000736 \cdot \mathrm{T}-0.00000273 \cdot \mathrm{T}^{2} \\
\mathrm{~K}_{1}=6.27-0.00938 \cdot \mathrm{T}-0.000303 \cdot \mathrm{T}^{2} \\
\mathrm{~K}_{2}=1.91+0.0407 \cdot \mathrm{T}-0.000293 \cdot \mathrm{T}^{2}
\end{gathered}
$$

In equations (3-6), W stands for material moisture content (\%); $\varphi$ is relative air humidity (\%); 1800 is the molecular weight of water multiplied by 100 ( $\mathrm{gram} / \mathrm{mol}) ; \mathrm{M}_{\mathrm{P}}$ is the molecular weight of the hydrateforming polymer (gram/mol); $\mathrm{n}$ is the number of adsorbed molecular layers; $\mathrm{K}_{\mathrm{i}}$ is the equilibrium constants between free and bound water in the wood; $\mathrm{T}$ stands for temperature $\left({ }^{\circ} \mathrm{C}\right)$.

The formulas for $K, K_{1}$ и $M_{P}$ factors calculation are given in Paper [6], equation (5).

Guggenheim-Anderson-de Boer model (GAB) is the result of BET theory development. It is described as

$$
\mathrm{w}=\frac{w_{0} \cdot \mathrm{K} \cdot \mathrm{c} \cdot \varphi}{(1-\mathrm{K} \cdot \varphi) \cdot(1-\mathrm{K} \cdot \varphi+\mathrm{K} \cdot \mathrm{c} \cdot \varphi)}
$$

Factors $\mathrm{c}$ and $\mathrm{K}$ are sorption constants related to the interaction energy between the first layer of adsorbed molecules and the following layers in the place of sorption:

$$
\begin{gathered}
c=c_{0} \cdot \exp \left[\frac{\mathrm{H}_{0}-\mathrm{H}_{\mathrm{n}}}{\mathrm{R} \cdot \mathrm{T}}\right] \\
\mathrm{K}=\mathrm{k}_{0} \cdot \exp \left[\frac{\mathrm{H}_{\mathrm{n}}-\mathrm{H}_{1}}{\mathrm{R} \cdot \mathrm{T}}\right],
\end{gathered}
$$

where $c_{0}, \mathrm{k}_{0}$ are entropy accommodation factors; $\mathrm{H}_{0}, \mathrm{H}_{\mathrm{n}}$ and $\mathrm{H}_{1}$ stand for the enthalpy of monolayer in the following layers and the liquid respectively. GAB model describes moisture sorption of materials in a wide range of relative air humidity values. Due to $\mathrm{K}$ factor in the equation it is possible to describe stages of aqueous vapor adsorption following the monomolecular stage up to the stage of liquid phase formation in the material pores. When $\mathrm{K}=1$ the equation transforms into BET equation [15].

Dent theory equation [16]:

$$
\mathrm{w}=\frac{\mathrm{b}_{1} \cdot \mathrm{b}_{\mathrm{i}} \cdot \varphi^{2} \cdot \mathrm{w}_{0}}{\left(1-\mathrm{b}_{\mathrm{i}}\right) \cdot\left(1-\mathrm{b}_{\mathrm{i}} \varphi+\mathrm{b}_{1} \cdot \varphi\right)}+\frac{\mathrm{b}_{1} \cdot \mathrm{w}_{0} \cdot \varphi}{1-\mathrm{b}_{1} \cdot \varphi \cdot \mathrm{b}_{\mathrm{i}} \cdot \varphi}
$$

Models $\mathrm{HH}$ and Dent can be reduced to the form (11).

$$
\mathrm{w}=\frac{\varphi}{\mathrm{C}+\mathrm{B}^{\cdot} \varphi+\mathrm{A}^{\cdot} \varphi^{2}}
$$

Factors $C, B$ and $A$ in Equation (11) are calculated by the following formulas:

$$
\begin{gathered}
C=\frac{1}{w_{0} \cdot b_{1}} \\
B=\frac{b_{1}-2 \cdot b_{i}}{w_{0} \cdot b_{1}} \\
A=\frac{b_{i}^{2}-b_{1} \cdot b_{i}}{w_{0} \cdot b_{1}}
\end{gathered}
$$

Nazirov R.A., Verkhovets S.V., Inzhutov I.S., Bazhenov R.V., Tarasov I.V. Moisture sorption models for wood. Magazine of Civil Engineering. 2016. No. 8. Pp. 26-36. doi: 10.5862/MCE.68.3 
For GAB model (7):

$$
\begin{gathered}
C=\frac{1}{c \cdot K \cdot w_{0}} \\
B=\frac{1}{w_{0}} \cdot\left(1-\frac{2}{c}\right) \\
A=\frac{k}{w_{0}} \cdot\left(\frac{1}{c}-1\right)
\end{gathered}
$$

Constants $b_{1}, b_{i}, w_{0}, K$ and $c$ can be calculated by solving the respective sets of equations.

Constants $A, B, C$ are calculated by empirical data approximation by means of Equation (11).

Even though the semi-empirical model $[17,18]$ does not have a fundamental theoretical basis, it describes sorption in the same or even a better way than other models above:

$$
w=a \cdot \varphi^{b}+c \cdot \varphi^{d}
$$

In the formula (19) $a, b<1, c n d>1$ are empirical constants.

In order to calculate the equilibrium moisture content of wood the following formulas [19] are used at $\varphi<0.5$ :

$$
w=a \cdot\left[b-\left(\frac{T}{100}\right)^{2}\right]+c \cdot \varphi \cdot\left[d-\left(\frac{T}{100}\right)^{2}\right]
$$

At $0.5<\varphi<1$ :

$$
w=\frac{a}{b-\varphi} \cdot\left[c-\left(\frac{T}{100}\right)^{2}\right]
$$

Factors $a, b$ и $c$ in formulas (19) and (20) have different numerical values.

Construction materials laboratory of Danish Technology University has published a list of moisture sorption values for a wide range of materials (including different species of wood and other construction materials), where the processes of adsorption and desorption are approximated by one equation [20] with different values of empirical constants $n, A$ and $w_{m}$ for forward and the backward process:

$$
w=w_{m} \cdot \exp \left[\left(-\frac{1}{n}\right) \cdot \ln \left(-\frac{\ln (\varphi)}{A}\right)\right]
$$

where $w_{m}$ stands for the maximum moisture content value.

The crucial meaning of moisture sorption for construction engineering is pointed out in dissertation works by V.G. Gagarin [21] and I.Y. Kiselyov [22]. In Paper [1] the moisture sorption capacity is calculated of construction materials is calculated by the following formula:

$$
w(\varphi, T)=\left(a_{m} \cdot T+b_{m}\right) \cdot\left[\frac{a_{a} \cdot \exp \left(b_{a} \cdot T\right)}{R \cdot T(-\ln (\varphi))}\right]^{a_{r} \cdot \exp \left(b_{r} \cdot T\right)}
$$

where $w$ is moisture sorption capacity $(\mathrm{kg} / \mathrm{kg}) ; \varphi$ is relative air humidity $(\mathrm{Pa} / \mathrm{Pa})$; $\mathrm{T}$ stands for temperature (K); $a_{a}, a_{m}, a_{r}, b_{a}, b_{m}, b_{r}$ are empirical constants.

The numerical values of empirical constants for some constructions materials are given in this paper.

For calculations with a fewer number of empirical factors the formula (22) can be presented in a more compact form without the first multiplier:

$$
w=\frac{\varphi \cdot c \cdot w_{0} \cdot\left(-\frac{a}{R \cdot T \cdot \ln (\varphi)}\right)^{\frac{1}{q}}}{\varphi \cdot c-\varphi+1}
$$

or: 


$$
w=\frac{\varphi \cdot c \cdot\left(-\frac{a}{\ln (\varphi)}\right)^{\frac{1}{q}}}{\varphi \cdot c-\varphi+1}
$$

Oswin empirical model [23]:

$$
w=A \cdot\left[\frac{\varphi}{1-\varphi}\right]^{B}
$$

With regard to ambient air temperature:

$$
w=\left(b_{m}+a_{m} \cdot T\right) \cdot\left[\frac{\varphi}{1-\varphi}\right]^{\frac{1}{q}}
$$

This is used at $\varphi<0,5$.

\section{Approximation quality evaluation method}

In order to evaluate the approximation quality of equilibrium water content value $w$ depending on relative air humidity $\varphi$, the following determination coefficient value was used:

$$
R^{2}=\frac{\sum_{i=1}^{n}\left(\breve{Y}_{i}-\bar{Y}_{i}\right)^{2}}{\sum_{i=1}^{n}\left(Y_{i}-\bar{Y}_{i}\right)^{2}}
$$

where $Y_{i}$ is the equilibrium moisture content of wood at different temperature and relative air humidity levels (Table 1). $\bar{Y}_{i}$ is the average equilibrium moisture content; $\breve{Y}_{i}$ stands for the values calculated by the above mathematical modeling formulas. The closer to $1 R^{2}$ is, the higher the quality of a certain model is rated. $Y_{i}$ values at different temperatures are listed in the Table 1 (taken from Paper [14]).

Table 1. Equilibrium moisture content of wood [14]

\begin{tabular}{|c|c|c|c|}
\hline \multirow{2}{*}{ Relative air humidity, $\boldsymbol{\varphi}$} & \multicolumn{3}{|c|}{ Moisture content of wood, $\boldsymbol{w} \mathbf{k g} \mathbf{k g}$ ) at the following temperatures } \\
\cline { 2 - 4 } & $\mathbf{- 1 . 1}{ }^{\circ} \mathbf{C}$ & $\mathbf{2 1 . 1}{ }^{\circ} \mathbf{C}$ & $\mathbf{4 3 . 3}{ }^{\circ} \mathbf{C}$ \\
\hline 0.05 & 0.014 & 0.013 & 0.011 \\
\hline 0.1 & 0.026 & 0.026 & 0.022 \\
\hline 0.15 & 0.037 & 0.035 & 0.032 \\
\hline 0.2 & 0.046 & 0.045 & 0.04 \\
\hline 0.25 & 0.055 & 0.054 & 0.049 \\
\hline 0.3 & 0.063 & 0.062 & 0.056 \\
\hline 0.35 & 0.071 & 0.069 & 0.063 \\
\hline 0.4 & 0.079 & 0.077 & 0.07 \\
\hline 0.45 & 0.087 & 0.085 & 0.077 \\
\hline 0.5 & 0.095 & 0.092 & 0.084 \\
\hline 0.55 & 0.104 & 0.101 & 0.092 \\
\hline 0.6 & 0.113 & 0.11 & 0.1 \\
\hline 0.65 & 0.124 & 0.12 & 0.11 \\
\hline 0.7 & 0.135 & 0.131 & 0.12 \\
\hline 0.75 & 0.149 & 0.144 & 0.132 \\
\hline 0.8 & 0.165 & 0.16 & 0.146 \\
\hline 0.85 & 0.185 & 0.179 & 0.166 \\
\hline 0.9 & 0.21 & 0.205 & 0.191 \\
\hline 0.95 & 0.243 & 0.239 & 0.224 \\
\hline
\end{tabular}

\section{Results and Discussion}

$R^{2}$ determination factor values describing data approximation for wood at different temperatures (the data taken from [14]) along with numerical values of the respective empirical factors are listed in the Table 2.

Nazirov R.A., Verkhovets S.V., Inzhutov I.S., Bazhenov R.V., Tarasov I.V. Moisture sorption models for wood. Magazine of Civil Engineering. 2016. No. 8. Pp. 26-36. doi: 10.5862/MCE.68.3 
Инженерно-строительный журнал, № 8, 2016

Table 2. Results of factors calculations in aqueous vapor adsorption equations for wood

\begin{tabular}{|c|c|c|c|c|c|c|c|}
\hline \multirow{3}{*}{$\begin{array}{c}\text { Sorption } \\
\text { model }\end{array}$} & \multirow{3}{*}{$\begin{array}{l}\text { Approximation } \\
\text { range }\end{array}$} & \multicolumn{6}{|c|}{ Calculation results at the following temperatures } \\
\hline & & \multicolumn{2}{|c|}{$-1.1^{\circ} \mathrm{C}$} & \multicolumn{2}{|c|}{$21.1^{\circ} \mathrm{C}$} & \multicolumn{2}{|c|}{$43.3^{\circ} \mathrm{C}$} \\
\hline & & $\begin{array}{c}\text { Determina } \\
\text {-tion } \\
\text { factor } R^{2}\end{array}$ & $\begin{array}{l}\text { Factors } \\
\text { values }\end{array}$ & $\begin{array}{c}\text { Determina } \\
\text {-tion } \\
\text { factor } R^{2}\end{array}$ & $\begin{array}{l}\text { Factors } \\
\text { values }\end{array}$ & $\begin{array}{c}\text { Determina } \\
\text {-tion } \\
\text { factor } R^{2}\end{array}$ & $\begin{array}{l}\text { Factors } \\
\text { values }\end{array}$ \\
\hline (2) & $\varphi=0.05 \ldots .0 .35$ & 0.9993 & $\begin{array}{c}w_{0}=0.062 \\
c=5.65\end{array}$ & 0.9986 & $\begin{array}{c}w_{0}=0.061 \\
c=5.50\end{array}$ & 0.9985 & $\begin{array}{c}w_{0}=0,058 \\
c=4.92\end{array}$ \\
\hline (5) & $\varphi=0.05 \ldots 0.95$ & 0.9998 & $\begin{array}{c}\mathrm{W}=245.833 \\
\mathrm{~K}=0.750818 \\
\mathrm{~K}_{1}=5.6847\end{array}$ & 0.9996 & $\begin{array}{c}\mathrm{W}=258.602 \\
\mathrm{~K}=0.7586 \\
\mathrm{~K}_{1}=6.0057\end{array}$ & 0.9995 & $\begin{array}{c}W=287.775 \\
\mathrm{~K}=0.7702 \\
\mathrm{~K}_{1}=5.8551\end{array}$ \\
\hline (6) & $\varphi=0.05 \ldots 0.95$ & 0.99999 & $\begin{array}{c}\mathrm{W}=348.939 \\
\mathrm{~K}=0.8046 \\
\mathrm{~K}_{1}=6.3287 \\
\mathrm{~K}_{2}=1.8891\end{array}$ & 0.99998 & $\begin{aligned} \mathrm{W} & =380.645 \\
\mathrm{~K} & =0.8186 \\
\mathrm{~K} 1 & =6.1195 \\
\mathrm{~K} 2 & =2.5410\end{aligned}$ & 0.99998 & $\begin{array}{c}\mathrm{W}=430.626 \\
\mathrm{~K}=0.8318 \\
\mathrm{~K}_{1}=5.4087 \\
\mathrm{~K}_{2}=3.0489\end{array}$ \\
\hline (7) & $\varphi=0.05 \ldots 0.95$ & 0.9998 & $\begin{array}{c}w_{0}=0.073 \\
c=6.68 \\
K=0.751\end{array}$ & 0.9996 & $\begin{array}{c}w_{0}=0.0696 \\
c=7.01 \\
K=0.759\end{array}$ & 0.9995 & $\begin{array}{c}w_{0}=0.0625 \\
\mathrm{c}=6.855 \\
K=0.770\end{array}$ \\
\hline (10) & $\varphi=0.05 \ldots 0.95$ & 0.9998 & $\begin{array}{c}w_{0}=0.07322 \\
b_{1}=5.019 \\
b_{i}=0.75018\end{array}$ & 0.9996 & $\begin{array}{c}w_{0}=0.06961 \\
b_{1}=5.3146 \\
b_{1}=0.7586\end{array}$ & 0.9995 & $\begin{array}{c}w_{0}=0.02549 \\
b_{1}=5.2795 \\
b_{1}=0.770169\end{array}$ \\
\hline (11) & $\varphi=0.05 \ldots .0 .95$ & 0.9998 & $\begin{array}{l}C=2.72 \\
B=9.57 \\
A=-8.72\end{array}$ & 0.9996 & $\begin{array}{c}C=2.70 \\
B=10.265 \\
A=-9.34\end{array}$ & 0.9995 & $\begin{array}{c}C=3.03 \\
B=11.32 \\
A=-10.517\end{array}$ \\
\hline (19) & $\varphi=0.05 \ldots 0.95$ & 0.99996 & $\begin{array}{l}a=0.163321 \\
b=0.793330 \\
c=0.119675 \\
d=6.489193\end{array}$ & 0.99994 & $\begin{array}{l}a=0.160191 \\
b=0.797828 \\
c=0.121444 \\
d=6.988122\end{array}$ & 0.99993 & $\begin{array}{l}a=0.148004 \\
b=0.816586 \\
c=0.118465 \\
d=7.26708\end{array}$ \\
\hline (20) & $\varphi=0.05 \ldots 0.5$ & 0.9975 & $\begin{array}{c}a=0.020 \\
b=7.851 \\
c=-0.0813 \\
d=5.241\end{array}$ & 0.9968 & $\begin{array}{c}a=-0.0202 \\
b=8.229 \\
c=-0.013 \\
d=-4.547\end{array}$ & 0.9967 & $\begin{array}{c}a=-0.00056 \\
b=-2.1318 \\
c=-0.06992 \\
d=12.281\end{array}$ \\
\hline (21) & $\varphi=0.5 \ldots 1.0$ & 0.9994 & $\begin{array}{l}a=0.051 \\
b=1.254 \\
c=8.088\end{array}$ & 0.9996 & $\begin{array}{c}a=0.00145 \\
b=1.246 \\
c=8.679\end{array}$ & 0.9997 & $\begin{array}{c}a=-0.1112 \\
b=1.231 \\
c=8.254\end{array}$ \\
\hline (22) & $\varphi=0.05 \ldots 0.95$ & 0.9975 & $\begin{array}{c}\mathrm{n}=0.824 \\
\mathrm{~A}=0.491 \\
w_{\text {max }}=0.27\end{array}$ & 0.9970 & $\begin{array}{c}\mathrm{n}=0.864 \\
\mathrm{~A}=0.444 \\
w_{\max }=0.264\end{array}$ & 0.9967 & $\begin{array}{c}\mathrm{n}=0.884 \\
\mathrm{~A}=0.403 \\
w_{\max }=0.25\end{array}$ \\
\hline (23) & $\varphi=0.2 \ldots 0.95$ & 0.9721 & $\begin{array}{c}\mathrm{a}_{\mathrm{m}}=0.0141 \\
\mathrm{~b}_{\mathrm{m}}=-0.5433 \\
\mathrm{a}_{\mathrm{a}}=0.019 \\
\mathrm{~b}_{\mathrm{a}}=0.0122 \\
\mathrm{a}_{\mathrm{r}}=0.0187 \\
\mathrm{~b}_{\mathrm{r}}=0.0112\end{array}$ & 0.9749 & $\begin{array}{c}\mathrm{a}_{\mathrm{m}}=0.0131 \\
\mathrm{~b}_{\mathrm{m}}=0.9398 \\
\mathrm{a}_{\mathrm{a}}=0.0135 \\
\mathrm{~b}_{\mathrm{a}}=0.01126 \\
\mathrm{a}_{\mathrm{r}}=0.0141 \\
\mathrm{~b}_{\mathrm{r}}=0.0113\end{array}$ & 0.9766 & $\begin{array}{c}\mathrm{a}_{\mathrm{m}}=0.0142 \\
\mathrm{~b}_{\mathrm{m}}=1.16 \\
\mathrm{a}_{\mathrm{a}}=0.0129 \\
\mathrm{~b}_{\mathrm{a}}=0.0101 \\
\mathrm{a}_{\mathrm{r}}=0.0154 \\
\mathrm{~b}_{\mathrm{r}}=0.0104\end{array}$ \\
\hline (24) & $\varphi=0.2 \ldots 0.95$ & 0.9987 & $\begin{array}{c}w_{0}=0.131 \\
c=2.32 \\
a=2075,41 \\
1 / q=0.229\end{array}$ & 0.9988 & $\begin{array}{c}w_{0}=0.093 \\
c=2.55 \\
a=7057,58 \\
1 / q=0.243\end{array}$ & 0.9988 & $\begin{array}{c}w_{0}=0.062 \\
c=2.57 \\
a=23583,6 \\
1 / q=0.256\end{array}$ \\
\hline (25) & $\varphi=0.2 \ldots 0.95$ & 0.9987 & $\begin{array}{c}c=2.32 \\
a=0.000126 \\
1 / q=0.229\end{array}$ & 0.9988 & $\begin{array}{c}c=2.55 \\
a=0.000166 \\
1 / q=0.243\end{array}$ & 0.9988 & $\begin{array}{c}c=2.57 \\
a=0.000172 \\
1 / q=0.256\end{array}$ \\
\hline (26) & $\varphi=0.05 \ldots 0.95$ & 0.9846 & $\begin{array}{c}A=0.0929 \\
B=0.358\end{array}$ & 0.9860 & $\begin{array}{c}A=0.0901 \\
B=0.361\end{array}$ & 0.9869 & $\begin{array}{c}A=0.0822 \\
B=0.369\end{array}$ \\
\hline (27) & $\varphi=0.05 \ldots 0.95$ & 0.9846 & $\begin{array}{c}a_{m}=175.83 \\
b_{m}=-47836 \\
1 / q=0.358\end{array}$ & 0.9860 & $\begin{array}{c}a_{m}=-24.247 \\
b_{m}=-7134.7 \\
1 / q=0.357\end{array}$ & 0.9869 & $\begin{array}{c}a_{m}=434 \\
b_{m}=-13792 \\
1 / q=0.333\end{array}$ \\
\hline
\end{tabular}

It is clear from the table that formulas (11) and (19) ensure the most accurate approximation (with the exception of Equation (6) which is the basis for the table in [14] and the Table 1).

Назиров Р.А., Верховец С.В., Инжутов И.С., Баженов Р.В., Тарасов И.В. Модели сорбционной влажности древесины // Инженерно-строительный журнал. 2016. № 8(68). С. $26-36$. 
As well as in Equation (6), the dependence of equilibrium moisture content on temperature in equations (11) and (19) is taken into account by considering the dependence of equation factors on temperature. For Equation (11):

$$
\begin{gathered}
A=-5.59 \cdot 10^{-4} \cdot T^{2}-0.0169 \cdot T-8.74 \\
B=3.69 \cdot 10^{-4} \cdot T^{2}+0.0239 \cdot T+9.60 \\
C=3.48 \cdot 10^{-4} \cdot T^{2}-7.77 \cdot 10^{-3} \cdot T+2.71
\end{gathered}
$$

For Equation (19):

$$
\begin{gathered}
a=-0.923 \cdot 10^{-5} \cdot T^{2}+4.50 \cdot 10^{-5} \cdot T+0.163 \\
b=1.45 \cdot 10^{-5} \cdot T^{2}-8.72 \cdot 10^{-5} \cdot T+0.793 \\
c=-0.5 \cdot 10^{-5}-20.0 \cdot 10^{-5} \cdot T+0.1199 \\
d=-22.3 \cdot 10^{-5} \cdot T^{2}+0.0264 \cdot T+6.52
\end{gathered}
$$

Figure 3 vividly illustrates the proximity of the calculated data when the dependence of empirical factors on temperature is taken into account.

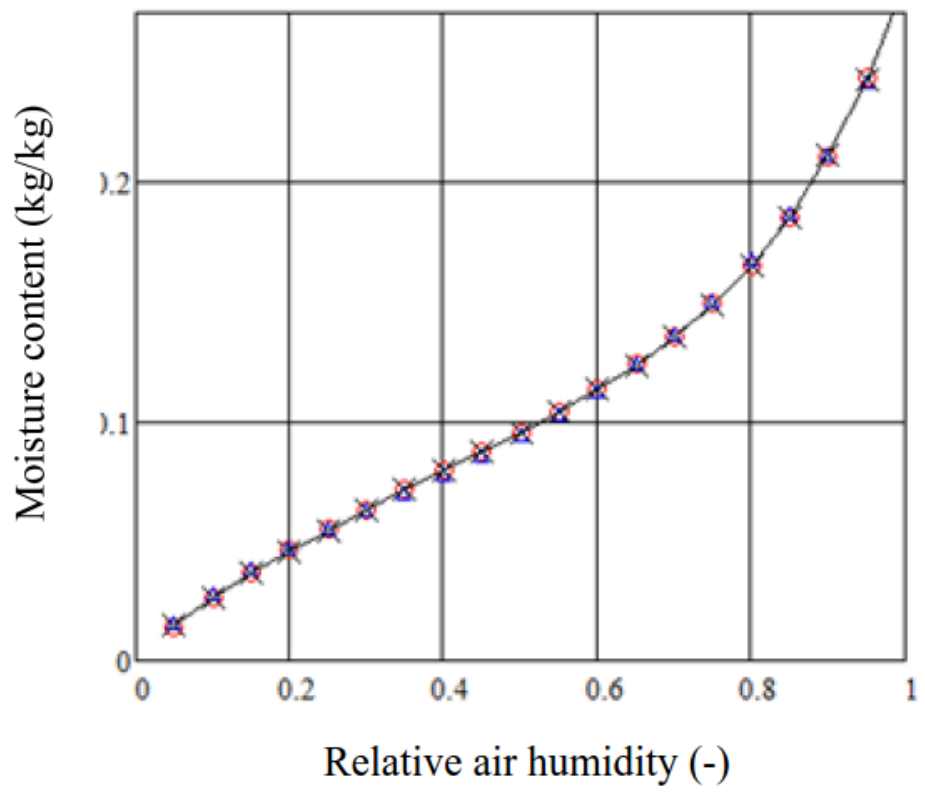

Figure 3. Calculation results comparison at the temperature of $-1.1^{\circ} \mathrm{C}$

- values published in [14]; $\Delta \Delta \Delta \quad$ - values calculated by Equation (11);

$\times \times \quad$ - values calculated by Equation (19)

\section{Conclusions}

A good level of sorption isotherm approximation at a constant temperature can be achieved using equations with three or four empirical constants for selection. The temperature dependence of sorption isotherm on $-1.1^{\circ} \mathrm{C}$ to $43.3^{\circ} \mathrm{C}$ with minimum possible coefficient of determination of R2 $\geqslant 0.9995$ can be considered by defining the dependence of empirical constants on temperature. Such accuracy is quite sufficient for the majority of practical engineering calculations. It is important to note that the high accuracy of factors selection for empiric and semi-empiric models in the form of rational function or in the form of the sum of two exponential functions with positive real numbers, such as modified equations of Hailwood-Horrobin (11) and Peleg (19), does not ensure the same accuracy when approximating experimental results for other materials that might not be error-free. However, when selecting models for calculations in a climatically defined range of air temperature and relative humidity values, these functions with minimum amount of empirical constants might be in preference to others.

Nazirov R.A., Verkhovets S.V., Inzhutov I.S., Bazhenov R.V., Tarasov I.V. Moisture sorption models for wood. Magazine of Civil Engineering. 2016. No. 8. Pp. 26-36. doi: 10.5862/MCE.68.3 


\section{References}

1. Kiselyov I.Ya. Vliyanie ravnovesnoy sorbtsionnoy vlazhnosti stroitelnykh materialov na soprotivlenie teploperedache naruzhnykh ograzhdayushchikh konstruktsiy [The effect of moisture sorption of construction materials on heat-transfer resistance of building envelope constructions]. Construction materials, the equipment, technologies of XXI century. 2014. No. 8 (187). Pp. 34-35. (rus)

2. Gagarin V.G., Pastushkov P.P., Reutova N.A. K voprosu o naznachenii raschetnoy vlazhnosti stroitelnykh materialov po izoterme sorbtsii [Defining the design humidity of construction materials on the basis of the sorption isotherm]. Building and Reconstruction. 2015. No. 4(60). Pp. 152-155. (rus)

3. Pastushkov P.P., Pavlenko N.V., Korkina E.V. Ispolzovanie raschetnogo opredeleniya ekspluatatsionnoy vlazhnosti teploizolyatsionnykh materialov [Using the calculated working humidity value of thermal insulation materials]. Building and Reconstruction. 2015. No. 4(60). P. 168-172. (rus)

4. Shepotilo M. Mnogojetazhnye doma iz drevesiny [Wood multi-storey buildings]. LesPromlnform. 2014. No. 3(101). Pp. 20-24 (rus)

5. Chudinov B.S. Voda v drevesine [Water in wood]. Novosibirsk: Nauka, 1984. 263 p. (rus)

6. Kolosovskaya E.A., Loskutov S.R., Chudinov B.S Fizicheskie osnovy vzaimodeystviya drevesiny $s$ vodoy [Physics of wood and water interaction]. Novosibirsk: Nauka, 1989. 216 p. (rus)

7. Brunauer S., Deming L.S., Deming W.E., Teller E. On a theory of the van der Waals adsorption of gases. J. Am Chem. Soc. 1940. No. 62(7). Pp. 1723-1732.

8. $\quad$ Sing K.S.W., Everett D.H., Haul R.A.W., Moscou L., Pierotti R.A., Rouquérol J., Siemieniewska T. Reporting physisorption data for gas/solid systems with special reference to the determination of surface area and porosity. Pure and Applied Chemistry. 1985. No. 57(4). Pp. 603619.

9. Andrade R.D.P., Lemus R.M., Pérez C.E.C. Models of sorption isotherms for food: uses and limitation. Vitae. 2011. No. 18(3). Pp. 325-334.

10. Simpson W.T. Sorption theories applied to wood. Wood Fiber Sci. 1980. No. 12(3). Pp. 183-195.

11. Brunauer S., Emmet P.H., Teller E. Adsorption of gases in multimolecular layers. J. Am. Chem. Soc. 1938. No. 60(2). Pp. 309-319.

12. Hailwood A.J., Horrobin S. Absorption of water of single model. Trans. Faraday Soc. 1946. No. 42B. Pp. 84-102.

13. Simpson W.T. Equilibrium moisture content prediction for wood. For. Prod. J. 1971. No. 21(5). Pp. 48-49.

14. Forest Products Laboratory. Wood handbook. Wood as an engineering material. Madison, 2010. 508 p.

15. Van den Berg C. Description of water activity of foods for engineering purposes by means of the G.A.B. model of sorption. In: B.M. McKenna (Ed.) Engineering and food. Elsevier Applied Science. 1984. Pp. 311-321.

16. Dent R.W., A multilayer theory for gas sorption. Part I: Sorption of a single gas. Textile Research Journal. 1977. No. 47. Pp. 145-152.

17. Peleg M. Assessment of a semi-empirical four parameter general model for sigmoid moisture sorption isotherms. $J$. Food Process Eng. 1993. No. 16. Pp. 21-37.

18. Ouafi N., Moghrani H., Benaouada N., Yassaa N., Maachi R., Younsi R. Moisture sorption isotherms and heat of sorption of algerian bay leaves. Maderas. Ciencia $y$ tecnología. 2015. No. 17(4). Pp. 759-772.

19. Krechetov I.V. Sushka drevesiny [Wood drying]. Lesnaya Promyshlennost, 1980. 427 p. (rus)

20. Hansen K.K. Sorption isotherms: a catalogue. Technical

\section{Литература}

1. Киселев И.Я. Влияние равновесной сорбционной влажности строительных материалов на сопротивление теплопередачи наружных ограждающих конструкций // Строительные материалы, оборудование, технологии XXI века. 2014. № 8 (187). С. 34-35.

2. Гагарин В.Г., Пастушков П.П., Реутова Н.А. К вопросу о назначении расчетной влажности строительных материалов по изотерме сорбции // Строительство и реконструкция. № 4(60). С. 152-155.

3. Пасушков П.П., Павленко Н.В., Коркина Е.В. Использование расчетного определения эксплуатационной влажности теплоизоляционных материалов // Строительство и реконструкция. № 4(60). С. 168-172.

4. Шепотило М. Многоэтажные дома из древесины // ЛесПромИнформ. 2014. № 3(101). С. 20-24.

5. Чудинов Б.С. Вода в древесине. Новосибирск: Наука, 1984. 263 c.

6. Колосовская Е.А., Лоскутов С.Р., Чудинов Б.С. Физические основы взаимодействия древесины с водой. Новосибирск: Наука, 1989. 216 с.

7. Brunauer S., Deming L.S., Deming W.E., Teller E. On a theory of the van der Waals adsorption of gases // J. Am. Chem. Soc. 1940. № 62(7). Pp.1723-1732.

8. Sing K.S.W., Everett D.H., Haul R.A.W., Moscou L., Pierotti R.A., Rouquérol J., Siemieniewska T. Reporting physisorption data for gas/solid systems with special reference to the determination of surface area and porosity // Pure and Applied Chemistry. 1985. № 57(4) Pp. 603-619.

9. Andrade R.D.P., Lemus R.M., Pérez C.E.C. Models of sorption isotherms for food: uses and limitation // Vitae. 2011. № 18(3). Pp. 325-334.

10. Simpson W.T. Sorption theories applied to wood // Wood Fiber Sci. 1980. № 12(3). Pp. 183-195.

11. Brunauer S., Emmet P.H., Teller E. Adsorption of gases in multimolecular layers // J. Am. Chem. Soc. 1938. № 60(2). Pp. 309-319.

12. Hailwood A.J., Horrobin S. Absorption of water of single model // Trans. Faraday Soc. 1946. № 42B. Pp. 84-102.

13. Simpson W.T. Equilibrium moisture content prediction for wood // For. Prod. J. 1971. № 21(5). Pp. 48-49.

14. Forest Products Laboratory. Wood handbook. Wood as an engineering material. Madison, 2010. 508 p.

15. Van den Berg C. Description of water activity of foods for engineering purposes by means of the G.A.B. model of sorption. In: B.M. McKenna (Ed.) // Engineering and food. Elsevier Applied Science. 1984. Pp. 311-321.

16. Dent R.W., A multilayer theory for gas sorption. Part I: Sorption of a single gas // Textile Research Journal. 1977. № 47. Pp. 145-152.

17. Peleg M. Assessment of a semi-empirical four parameter general model for sigmoid moisture sorption isotherms // J. Food Process Eng. 1993. № 16. Pp. 21-37.

18. Ouafi N., Moghrani H., Benaouada N., Yassaa N., Maachi R., Younsi R. Moisture sorption isotherms and heat of sorption of algerian bay leaves // Maderas. Ciencia y tecnología. 2015. № 17(4). Pp. 759-772.

19. Кречетов И.В. Сушка древесины. Лесная промышленность, 1980. 427 c.

20. Hansen K.K. Sorption isotherms: a catalogue. Technical report 162/86. Building Materials Laboratory. The Technical University of Denmark, 1986. 142 p.

21. Гагарин В.Г. Теория состояния и переноса влаги в строительных материалах и теплозащитные свойства ограждающих конструкций. Дисс. на соиск. учен.степ к.т.н.: Спец. 05.23.01, 05.23.03. М., 2000. 396 с.

Назиров Р.А., Верховец С.В., Инжутов И.С., Баженов Р.В., Тарасов И.В. Модели сорбционной влажности древесины // Инженерно-строительный журнал. 2016. № 8(68). С. 26-36. 
report 162/86. Building Materials Laboratory. The Technical University of Denmark, 1986. $142 \mathrm{p}$.

21. Gagarin V.G. Teoriya sostoyaniya i perenosa vlagi v stroitelnykh materialakh i teplozashchitnye svoystva ograzhdayushchikh konstruktsiy zdaniy [Theory of moisture state and transfer in construction materials and heatprotective features of building envelope constructions]. $\mathrm{PhD}$ dissertation. NIISF. Moscow, 2000. 396 p. (rus)

22. Kiselyov I.Ya. Povyshenie tochnosti opredeleniya teplofizicheskikh svoystv teploizolyatsionnykh stroitelnykh materialov $s$ uchetom ikh struktury i osobennostey ekspluatatsionnykh vozdeystviy [Accuracy improvement in defining heat-transfer and heat-resistance properties of thermal insulation construction materials with regard to their structure and application environment effects]. PhD dissertation. NIISF. Moscow, 2006. 366 p. (rus)

23. Oswin C.R. The kinetics of package life. III. Isotherm. J. Soc. Chem. Ind. 1946. No. 65(12). Pp. 419-421.

Rashit Nazirov,

+7(902)9904593; nazirovra@gmail.com

Sergey Verkhovets,

+79029237798; sverhovec@sfu-kras.ru

Ivan Inzhutov,

+7(913)5228690; ivaninzhutov@gmail.com

Roman Bazhenov,

+79233132387; bazhenovrv@gmail.com

Igor Tarasov,

+79135148510; tarasovs_box@mail.ru
22. Киселев И.Ю. Повышение точности определения теплофизических свойств теплоизоляционных строительных материалов с учетом их структуры и особенностей эксплуатационных воздействий. Дисс. на соиск. учен.степ к.Т.н.: Спец. 05.23.01. М., 2006. 366 c.

23. Oswin C.R. The kinetics of package life. III. Isotherm // J. Soc. Chem. Ind. 1946. № 65(12). Pp. 419-421.
Рашит Анварович Назиров, $+7(902) 9904593$;

эл. почта: nazirovra@gmail.com

Сергей Владимирович Верховец, +79029237798;

эл. почта: sverhovec@sfu-kras.ru

Иван Семенович Инжутов, $+7(913) 5228690$;

эл. почта: ivaninzhutov@gmail.com

Роман Владимирович Баженов, +79233132387;

эл. почта: bazhenovrv@gmail.com

Игорь Владимирович Тарасов,

+79135148510; эл. почma: tarasovs_box@mail.ru

(C) Nazirov R.A., Verkhovets S.V., Inzhutov I.S., Bazhenov R.V., Tarasov I.V., 2016

Nazirov R.A., Verkhovets S.V., Inzhutov I.S., Bazhenov R.V., Tarasov I.V. Moisture sorption models for wood. Magazine of Civil Engineering. 2016. No. 8. Pp. 26-36. doi: 10.5862/MCE.68.3 